\title{
OPTIMIZATION OF NUTRITION AND ACCUMULATION OF ABOVEGROUND BIOMASS BY TRITICALE PLANTS
}

\section{Gamayunova V. V., Chaikina O. I.}

\section{INTRODUCTION}

Ukraine is known worldwide as a producer of high-quality grain. State programs for the development of Agriculture for $2020 \mathrm{yr}$ provide for an increase in grain production up to 80 million tons.

Of this amount, almost half of the planned shaft, namely 35.6 million tons of winter wheat were allocated. The availability of adapted varieties and modern technologies allow such tasks to be really performed. However, weather instability, both during the sowing season and during the winter, makes some adjustments annually to the problem of stabilizing the yield of winter crops.

This issue depends to a certain extent on the level of frost and winter hardiness of crops and even selection of individual varieties. At the same time, it is known that in extreme difficult weather conditions, this characteristic of these winter crops should be taken into account when compiling the structure of sown areas. This feature should be taken into account when drawing up the structure of sown areas.

So far, winter crops are generally represented and provide the planned volume of production mainly due to winter wheat, and rye and triticale are still little grown, although they are more winter-resistant than wheat. For stable grain production in all years of growing, regardless of the weather conditions of vegetation, for reducing risks, for example, in the Left-Bank Forest-Steppe of Ukraine they propose to include $85-88 \%$ of soft wheat, rye and triticale $10-12 \%$ in the structure of winter crops, as well as $3-5 \%$ of the area to occupy Barley ${ }^{1}$.

If it is necessary to re-sow winter crops, in spring, as a rule, the area is occupied by spring barley, much less by spring wheat and even less by

${ }^{1}$ Рябчун Н. І. Методологічні основи визначання зимостійкості, моніторингу посівів та формування урожайності озимих зернових культур : автореф. дис. ... д-ра с.-г. наук, спец. 06.01.09. Харків, 2015. С. 31. 
triticale, although there is a need and demand for grain of this valuable crop ${ }^{2}$.

\section{Literature review}

Triticale is a relatively new winter or spring plant that is artificially created by crossing rye with wheat. It is grown as a food and grain crop in the same regions as winter wheat and rye. Triticale varieties have a high agroecological plasticity to growing zones and their winter hardiness is dominated by winter wheat varieties.

As for the development and phenophases, triticale plants have the same stages of organogenesis as rye and wheat. These crops are characterized by a well-developed root system and they are able to absorb nutrients better than wheat. It also bushes more intensively than rye and wheat. The crops are relatively new, as triticale has been grown for more than 120 years, while barley and wheat are about 10 thousand years old, and Rye is 7 thousand years old. Triticale grain is larger than rye and wheat and contains $1.5-2.0 \%$ more protein than the latter, but it is characterized by a rather sticky and stretchable gluten, which is why it has worse baking and technological qualities compared to wheat.

Triticale flour is widely used for the production of high-quality cookies and cakes due to such property, since it contains low-quality gluten. Triticale bread is white, almost the same as wheat bread, but inferior to it in volume, it is somewhat sweet and useful for diabetics and people prone to obesity.

Triticale grain, due to its high enzymatic activity, can be successfully used in the alcohol-burning, brewing industry and for the production of starch.

This crop is suitable for growing in most regions of Ukraine (steppe, forest-steppe, Polesie) and with high agricultural technology it is able to form a grain yield of 5-6, and yield of green mass of 45-55 t/ha. Therefore, it can be widely used for the manufacture of food products and in fodder production. There is evidence that the addition of $30 \%$ triticale grain to mixed fodder contributes to a significant increase in young cattle.

2 Гамаюнова В. В., Дворецький В. Ф., Сидякіна О. В., Глушко Т. В. Формування надземної маси ярих пшениці та тритикале під впливом оптимізації їх живлення на Півдні України. Вісник ЖНАЕУ. Житомир, 2017. № 2 (61). T. 1. C. 23. 
Given the still insignificant area under this crop in Ukraine and its value, it is necessary to develop and improve the main elements of agricultural technology for growing triticale in all areas of the country. We conducted a study on spring triticale (2014-2016 yrs) and winter crops (2017-2020 yrs), studied one of the main factors influencing the formation of crop productivity such as nutrition optimization, which occupies the second line among all the components of growing technology, the first most limiting factor is moisture. The growth processes of triticale plants, growth of height, aboveground biomass, leaf surface area, and so on were studied. After all, regardless of the growing area and crop, an important role in the development of plants is played by aboveground biomass, from which they mobilize carbohydrates and nitrogen-containing substances to form a productive part of the crop. Therefore, the formed aboveground apparatus already from the initial phases of plant growth processes acts, as a rule, as a prerequisite for obtaining stable crops. According to the results of a number of studies conducted with many crops, a close relationship was established between the level of yield and accumulated biomass.

This issue is particularly relevant in the south of Ukraine, including due to the growing aridity and temperature regime. After all, under such conditions in grain plants, part of the leaf apparatus dies off already in the grain filling phase ${ }^{3}$. The increase in aboveground biomass of plants is facilitated by optimal provision of all the necessary elements of nutrition, moisture and other factors. Accordingly, when creating the desired parameters of plant habit, you can expect maximum crop productivity. That is, all the factors and elements of technology that ensure the growth of the aboveground apparatus affect upon the internal processes occurring in plants and the level of future yield ${ }^{4,5}$. To the greatest extent,

3 Біднина І. О., Влащук О. С., Козирєв В. В., Томницький А. В. Ефективність сумісного застосування добрив та мікробних препаратів при вирощуванні сільськогосподарських культур на Півдні України. Зрошуване землеробство. Херсон, 2013. № 60. С. 55.

${ }^{4}$ Господаренко Г. М., Любич В. В. Реакція сортів тритикале ярого на рівень азотного живлення. Збірник наукових пращь Уманського державного аграрного університету. Серія Агрономія. Умань, 2009. Вип. 72. Ч. 1. С. 23.

${ }^{5}$ Гамаюнова В. В., Дворецький В. Ф., Сидякіна О. В. Формування врожаю тритикале ярого залежно від фону живлення та передпосівного оброблення насіння. Наукові горизонти, «Scientific Horizons». Zhytomyr, 2018. № 7-8 (70). C. 7. 
this is influenced by plant nutrition and, above all, providing them with nitrogen ${ }^{6,7}$.

Thus, as many researchers have determined, the growth processes and accumulation of aboveground biomass by plants are quite strongly determined by the conditions of their nutrition. Thus, in the conditions of the Mykolaiv region, even low doses of nitrogen fertilizer increased bushiness, the number of nodal roots and the growth of the aboveground part of spring wheat plants ${ }^{8}$. Other researchers report on these positives of nitrogen nutrition, pointing out that with their lack, spring wheat is weakly bushy, it forms little leaves (it forms a poorly developed area of the assimilation surface) and, accordingly, it sharply reduces its productivity, too ${ }^{9}$. Similarly, the optimization of nutrition and, above all, the supply of nitrogen compounds to plants, as we have already noted, affects the growth and development of triticale plants ${ }^{10}$.

Triticale (Triticosecale) is a winter or spring cereal plant artificially created by breeders by crossing rye with wheat. The plant's name Triticale, Triticosecale, comes from the Latin names of wheat (Triticum L.) and rye (Secale L.). Triticale exceeds both parent plants in a number of key characteristics (yield, nutritional value), and in terms of resistance to adverse weather conditions and disease damage, it exceeds wheat and is not inferior to Rye, as we noted.

Triticale grain does not provide high-quality bread products due to the low gluten quality. However, white bread in terms of taste is almost

6 Любич В. В. Вплив азотного живлення на врожайність і кормові властивості зерна тритикале ярого. Науковий вісник Львівського національного університету ветеринарної медицини та біотехнологій ім. С. З. Гжицького. Львів, 2009. Т. 11. № 2-3 (41). С. 133.

7 Філоненко Т. А. Забезпеченість сільськогосподарських культур елементами живлення та їх урожайність залежно від застосування зростаючих доз азотних добрив. Вісник Харківського національного аграрного університету. Серія: Грунтознавство, агрохімія, землеробство, лісове господарство. Харків, 2015. № 1. С. 134.

${ }^{8}$ Андрійченко Л. В. Шляхи підвищення врожайності та якості зерна твердої ярої пшениці на Півдні України. Вісник аграрної науки Причорномор'я. Миколаїв, 2006. С. 31.

${ }^{9}$ Шевніков Д. М. Вплив мінеральних добрив на поживний режим грунту за вирощування пшениці твердої ярої. Вісник Полтавської державної аграрної академії. Полтава, 2012. № 2. С. 204.

10 Білітюк А. П. Агротехнологічні основи вирощування тритикале в Україні. Агроном: науково-виробничий журнал. Київ : ТОВ «Агромедіа», 2005. № 3. C. 27. 
the same as wheat bread from high-quality flour, has a pleasant taste and aroma, specialists have already developed new technologies for factory baking bread varieties from a mixture of triticale and wheat. Scientists emphasize that triticale grain belongs to the most promising types of plant raw materials for expanding the range of Healthy Food Products, Functional Food Additives, since it exceeds wheat and rye in terms of protein, amino acids, vitamins, macro- and microelements, and biologically active substances ${ }^{11}$.

Modern varieties of triticale, in particular Ukrainian selection, are sown to produce green fodder, silage, hay. Given that triticale grain is a good source of protein with a balanced amino acid composition, and it also surpasses other cereals in terms of digestible protein content, increasing of its production will provide animal husbandry with high quality grain feed. Straw is also used for animal feed, as bedding for livestock, or as an organic fertilizer. Triticale is still grown in Ukraine on a limited area (up to 100 thousand hectares). This is explained by the fact that its ears easily break off during maturation and harvesting is difficult; in some years, there is also a significant grain gap and the grain is formed puny ${ }^{12}$.

Triticale has a well-developed root system, which after grain germination prevails in wheat growth, as well as due to the presence of a significant waxy coating of triticale on the shoots and winter wheat prevails in drought resistance. This is especially noted for the varieties ADM-8, Kievskoe Rannye, Amphiploid 296, which can withstand drought well throughout the growing season. However, in most other varieties, in dry weather, during the period of intensive growth of the vegetative mass (in the stooling phase and even more so during the formation and pouring of grain, when the lack of moisture delays the growth of grain and the deposition of organic substances in it), the fine grain is formed, weighing 1000 PCs. which does not exceed 35-40 G instead of the usual mass of about 50-55 G. Soil moisture at $70 \% \mathrm{HV}$ is favorable for triticale.

11 Медведев А. М., Медведева Л. М. О недостатках и преимуществах тритикале в сравнении с другими зерновыми растениями. Тритикале России : материаль заседания секции тритикале. Ростов-наДону : РАСХН, 2008. T. 67. C. 143.

12 Білітюк А. П., Шустер Н. Ф. Вирощування інтенсивних агроценозів тритикале озимого в умовах Західного Полісся України. Збірник наукових праць Волинського інституту АПВ. Луцьк, 2006. С. 77. 
In terms of frost resistance, triticale occupies an intermediate place between winter wheat and rye, it withstands temperature drops at the depth of the tillering node to minus $17-19^{\circ} \mathrm{C}$, sometimes up to minus $20^{\circ} \mathrm{C}$, and in terms of winter hardiness it is more close to winter wheat. For Ukrainian farmers, harvesting, as a rule, is extremely difficult. Moisture deficiency in autumn and frosty spring make their adjustments to the plans of agricultural producers of almost all of Ukraine and can provoke a significant shortage of winter wheat yields, therefore, the high potential of triticale grain yield and green mass, increased adaptive properties to unfavorable conditions (winter hardiness, drought resistance, soil unpretentiousness, resistance to fungal diseases) and the high quality of the grain has ensured that this crop is recognized in the world as both food and fodder.

The culture is most widely distributed in Poland, where its area reached 1.258 million square meter hectares. In $2010 \mathrm{yr}$, Belarus grew more than 425 thousand hectares of triticale. And the highest yield indicators were achieved by Germany as 5.4 up to 5.7 t/ha of grain for growing on an area of 404.4 thousand hectares.

Currently, there are no official statistics on acreage and triticale grain production in Ukraine. According to unofficial data of the Volyn state agricultural Experimental Station (DSGDS) of the Institute of Agriculture of Western Polesie of the National Academy of Sciences (ISGZP) and the V. Y. Yuryev Institute of crop production, almost 200 thousand hectares are occupied under crops, of which about 80 thousand hectares are located spring triticale. The main areas of winter triticale are located in Volyn, Dnipropetrovsk, Donetsk, Kharkiv areas of spring triticale are in Poltava and Lviv regions.

So triticale in terms of yield and nutritional value exceeds both parent plants, and in terms of resistance to adverse weather conditions and disease damage exceeds wheat and is not inferior to rye. Therefore, the expansion of winter triticale sowing areas in the modern period will allow farmers of Ukraine to steadily receive high grain yields with a reduction in the risk of grain shortages in extreme weather years ${ }^{13}$.

Now this is extremely important, as every year there are changes in climatic conditions in the direction of increasing aridity, in which the

13 Щипак Г. В., Петрова А. П., Шевченко Е. Н., Щипак В. Г. Результаты селекции озимой тритикале на урожайность, зимостойкость и качество зерна. Вісник ЦНЗ АПВ. Харків, 2010. Вип. 9. С. 183. 
triticale crop will be able to contribute to the fulfillment of the task of balancing grain production in our country.

The analysis of literature sources and our previous studies with the triticale spring in particular for the effects on the patterns of growth and development of plants of nutritional optimization with the addition of modern biologics to this event, gave us grounds for conducting experiments in this direction with winter triticale culture.

\section{Purpose, objectives and methodology of the research}

The purpose of the research was to develop and study questions on improving the nutrition of plants of the triticale of spring and winter. Spring triticale of the Kharkiv Solovey variety and winter triticale of the Bouquet variety were taken for study. Schemes of experiments with spring triticale are given in the corresponding tables.

Research on spring triticale was carried out on Southern chornozem in the National Research Center of Mykolaiv NAU during 2014-2016 yrs and on winter triticale it was on common chornozem in the conditions of the farm "Veles Krivoozerschina", which was located in the Krivoozersky District of Mykolaiv region in 2017-2020 yrs.

In addition to mineral fertilizers, in the doses recommended for the study zone, resetting substances and biologics were also used, in particular, when growing spring triticale, they treated seeds before sowing and plant crops in the phase of plants entering the tube once and twice for vegetation - except for the previous one at the beginning of spiking. Seeds on the day of sowing were processed manually by EscortBio $-50 \mathrm{ml}$ of the drug per hectare rate of seeds at $1.0 \%$ concentration of the working solution. Plant crops were treated with biopreparations: Organo-mineral fertilizer D2 $(1.0 \mathrm{l} / \mathrm{ha})$ and Escort-Bio $(0.5 \mathrm{l} / \mathrm{ha})$ at the rate of a working solution of $200 \mathrm{l} / \mathrm{ha}$.

When growing winter triticale, in addition to mineral nitrogen fertilizers, modern growth stimulators as Rost Concentrate and MicroMineralis were used to treat sowing plants in the tillering phase, stooling and starting earing in doses of $1.5 \mathrm{l} / \mathrm{ha}$ with a loss of a working solution of $200 \mathrm{l} / \mathrm{ha}$.

\section{Research results}

Studies with winter triticale were conducted according to the following scheme:

1 - monitoring; $2-\mathrm{N}_{30}$ (to sow) - background; 3 - background + $\mathrm{N}_{40}$ (in the spring bush); 4 - background + treatment of plants 
(in the bush phase, plant entry into the tube, beginning of spiking) with ROST-concentrate growth stimulants; 5 - background + treatment of plants (in the bush phase, plant entry into the tube, beginning of spiking) with Micro-Mineralis growth stimulants.

Studies have determined that the increases in the above-ground biomass of plants triticale both spring and winter, significantly influenced the created backgrounds of nutrition by applying fertilizers and using biologics taken for study. In particular, in spring triticale plants, the intensity of biomass accumulation during the main periods of vegetation grew under the influence of both fertilizers and plant feeding, and under the influence of pre-treatment of seeds (Fig. 1).

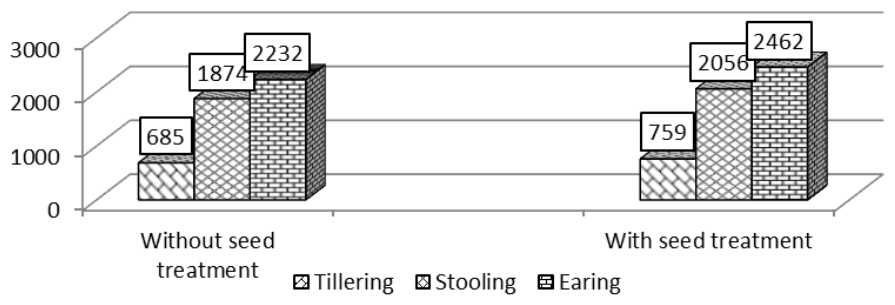

Fig. 1. Accumulation of raw aboveground biomass by spring triticale plants (average power factor for 2014-2016 yrs), $\mathrm{g} / \mathrm{m}^{2}$

With a similar dependence, the accumulation of dry above-ground biomass by plants changed (Table 1.), because this indicator is calculated.

The data in Fig. 1 and Table. 1 show a positive effect of nutritional optimization on the growth of aboveground biomass by spring triticale plants. So, on average, over the years of research, already in the tillering phase, only under the influence of pre-sowing seed treatment, raw biomass increased by $10.8 \%$, and dry biomass increased by $11.8 \%$. These indicators of growth of raw and dry biomass were also quite close in subsequent periods of determination (in the phases of plant stooling and earing - In the range of 9.7 up to $10.1 \%$ ). We also determined the average daily growth of plants of raw and dry biomass in the main interfacial periods depending on the pre-treatment of seeds and plants, that is, by optimizing their nutrition (Fig. 2). 
Table 1

Influence of background nutrition, treatment of seeds and plants of spring triticale on formation

of dry above-ground biomass (average for 2014-2016 yrs), $\mathrm{g} / \mathrm{m}^{2}$

\begin{tabular}{|c|c|c|c|c|c|c|}
\hline \multirow{3}{*}{$\begin{array}{l}\text { Variant of nutrition } \\
\quad \text { (factor } A)\end{array}$} & \multicolumn{2}{|c|}{$\begin{array}{c}\text { Without seed } \\
\text { treatment }\end{array}$} & \multicolumn{4}{|c|}{ With seed treatment } \\
\hline & \multicolumn{6}{|c|}{ (factor B) } \\
\hline & 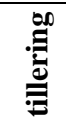 & 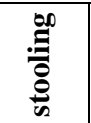 & 苞 & 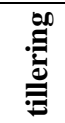 & 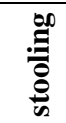 & 胥 \\
\hline 1. without fertilizers - control & 95 & 213 & 420 & 105 & 230 & 455 \\
\hline $\begin{array}{l}\text { 2. } \mathrm{N}_{30} \mathrm{P}_{30} \text { before sowing - } \\
\text { background }\end{array}$ & 115 & 282 & 590 & 131 & 312 & 653 \\
\hline 3. $\mathrm{N}_{60} \mathrm{P}_{30}$ before sowing & 198 & 440 & 695 & 222 & 482 & 785 \\
\hline $\begin{array}{c}\text { 4. Background }+\mathrm{N}_{30} \\
\text { (ammonium nitrate in Phase 1) }\end{array}$ & 125 & 457 & 713 & 140 & 512 & 800 \\
\hline 5. Background $+\mathrm{D}_{2}$ (in Phase 1) & 120 & 438 & 642 & 134 & 482 & 705 \\
\hline 6. Background + Escort (in Phase 1) & 119 & 435 & 650 & 132 & 480 & 710 \\
\hline 7. Background $+\mathrm{D}_{2}$ (in Phase $1 \& 2$ ) & 124 & 445 & 640 & 138 & 484 & 706 \\
\hline $\begin{array}{l}\text { 8. Background + Escort } \\
\text { (in Phase } 1 \& 2 \text { ) }\end{array}$ & 122 & 440 & 641 & 135 & 478 & 705 \\
\hline $\begin{array}{l}\text { 9. Background }+\mathrm{N}_{30} \\
\text { (Urea in Phase 2) }\end{array}$ & 122 & 435 & 630 & 138 & 482 & 692 \\
\hline
\end{tabular}

"Notes: Phase 1 - plants entering the tube

Phase 2 - beginning of spiking

As established by our studies and definitions, this indicator, under the influence of the factors that took on the study, increased, especially for feeding on the background of seed treatment before sowing.

In the same way, under the influence of mineral fertilizers and resetting biologics, the accumulation of above-ground biomass by winter triticale plants occurred and changed (Fig. 3). 


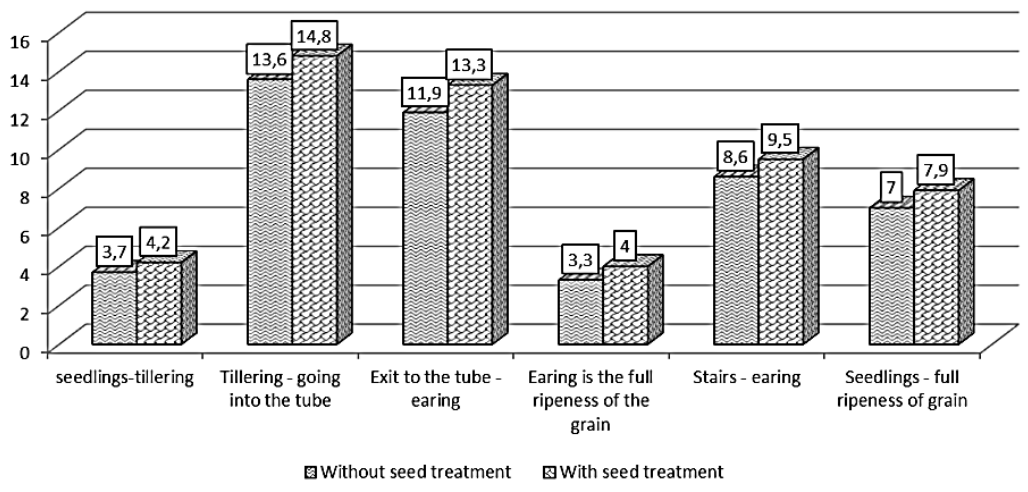

Fig. 2. Average daily increase of dry aboveground mass by spring triticale plants on average by Factor A (average for 2014-2016 yrs), g/ $\mathrm{m}^{2}$

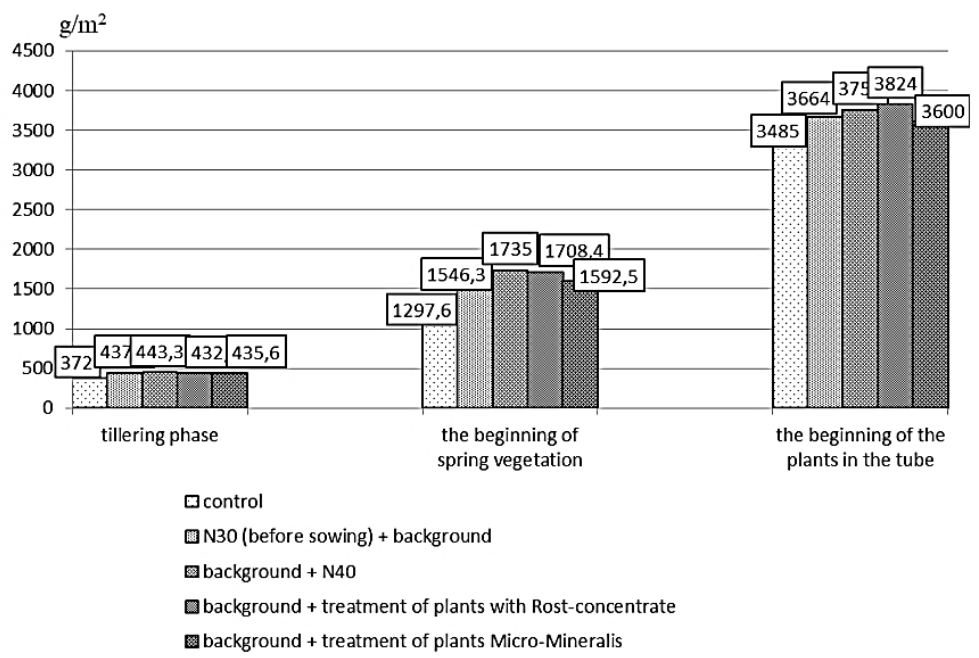

Fig. 3. Growth of aboveground biomass by winter triticale plants under the influence of nutrition (average for 2017-2020 yrs), $\mathrm{g} / \mathrm{m}^{2}$

Starting from the tillering phase, winter triticale plants accumulated biomass most intensively during early spring top dressing with nitrogen at a dose of $\mathrm{N}_{40}$ (variant 3). That is, plants immediately after the introduction of fertilizer began to respond to its use by intensively increasing the growth of above-ground biomass. This trend persisted 
until the beginning of the spring growing season. Slightly smaller increases were provided by the treatment of winter triticale crops with Micro-Mineralis and Rost Concentrate. Re-regulating preparations after the second feeding of plants (at the beginning of entering the tube) do not differ, even acquire a slight advantage compared to $\mathrm{N}_{40}$, and especially due to the treatment of seeding with Rost concentrate.

At the same time, it should also be noted that the aboveground biomass of winter triticale plants increased with different intensity depending on the variants for using fertilizers (mineral nitrogen) and fertilizing with growth stimulants in individual years of cultivation. At the lowest rate, this occurred depending on the conditions that they developed during certain periods of vegetation of plants. So, in the conditions of the driest autumn of 2017 yr. during the tillering phase, the aboveground biomass of plants was determined to be the lowest compared to other years, and already at the beginning of the resumption of spring vegetation in the following $2018 \mathrm{yr}$, plants grew with significant intensity and the accumulated aboveground biomass did not differ significantly compared to subsequent years of research. On the contrary, during this period of sampling and determination, the smallest biomass was accumulated by plants in 2020. This indicates that the formation of the green mass of winter triticale is significantly influenced by weather conditions - the temperature regime and the amount of atmospheric precipitation for the general period and in the section of individual vegetation phases. Feeding three times for vegetation in all the phases determined by the scheme (bushes, plant entry into the tube and spikes) ensures the accumulation of a significant amount of green mass in the case of using and beveling plants of winter-to-feed animals that often take place in farms (Fig. 4). 


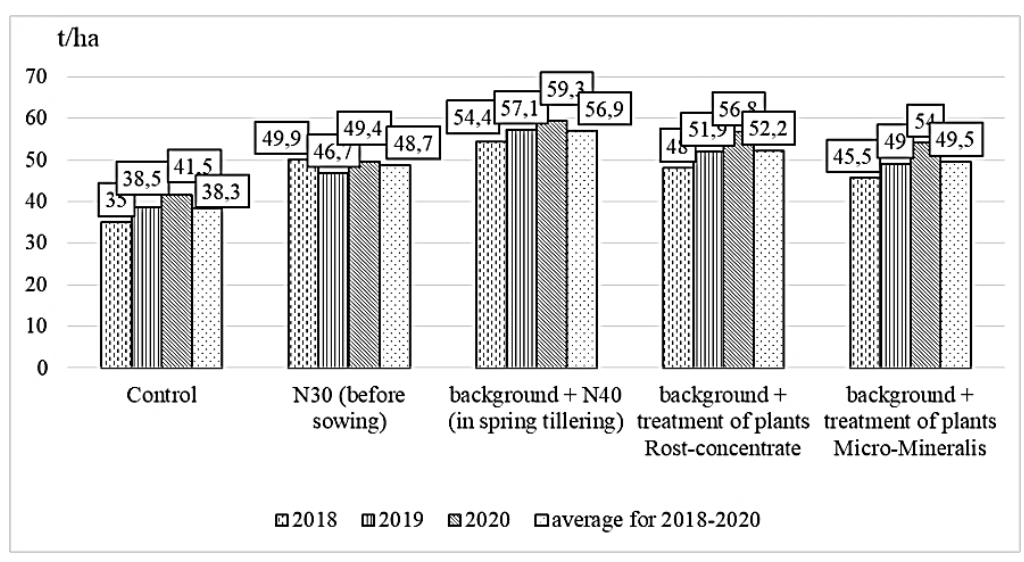

Fig. 4. Yield of aboveground green biomass triticale winter depending on nutritional optimization during growing years, $t / h a$

It seems that there is a fairly close relationship between the accumulated biomass of all agricultural crops, including cereals, and the number, mass of leaves and the area of their assimilation surface. Let's show this with the example of spring triticale, the leaf area of whose plants grew under the influence of nutrition optimization.

For most grain crops, the optimal leaf surface area is 35-50 thousand $\mathrm{m}^{2} / \mathrm{ha}$, and the photosynthetic potential is $1.8-2.0$ million ton $\mathrm{m}^{2} \mathrm{x}$ days/ha ${ }^{1415}$.

The formation of the leaf apparatus of plants is influenced by many factors, among which the level of mineral nutrition plays an important role. By optimizing the nutrient regime, it is possible to increase both the size and productivity of the assimilation surface of plants. This is also confirmed by the results of our research. According to the data obtained, during the growing season, the leaf surface area of fertilized spring triticale plants was larger than that of unfertilized ones. It reached its maximum size in all variants of the experiment during the earing phase (Fig. 5).

${ }^{14}$ Синеговская В. Т., Абросимова Т. Е. Активизация фотосинтетической деятельности яровой пшеницы при длительном применении удобрений. Вестник Российской академии с.-х. наук. 2006. № 5. С. 48.

${ }^{15}$ Gamayunova V., Sydiakina O., Dvoretskyi V., Markovska O. Productivity of Spring Triticale under Conditions of the Southern Steppe of Ukraine. Ecological Engineering \& Environmental Technology. 2021. № 22(2). P. 107. 


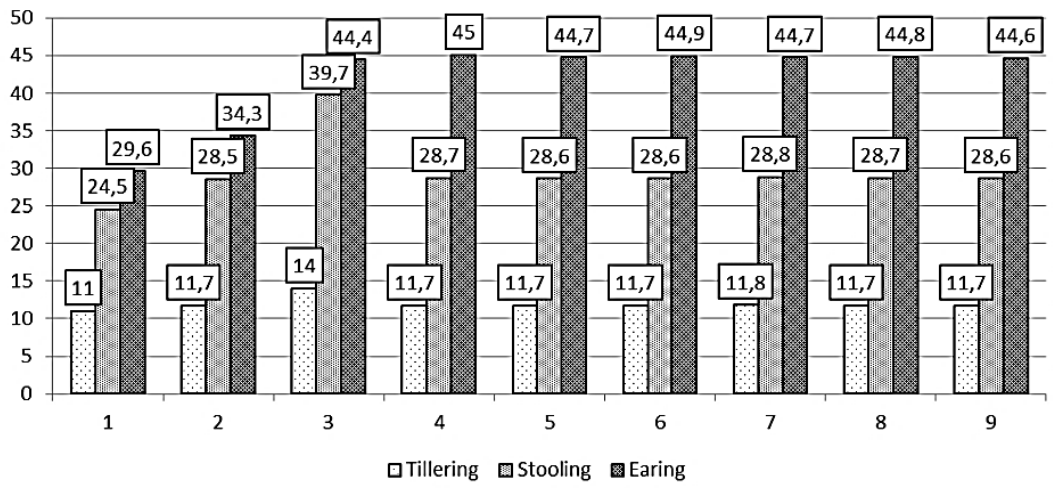

Fig. 5. Influence of nutrition optimization on the leaf surface area of spring triticale during the main growing season (average for 2014-2016 yrs), thousand $\mathrm{m}^{2}$ / ha

The polynomial correlation and regression relationships calculated by us between the leaf surface area and the grain yield of the crop showed that in the tillering phase and the stooling phase, there is a significant relationship between these indicators, both in variants with pre-sowing seed treatment and without treatment. The coefficient of determination (R2) for spring triticale ranges from 0.579 to 0.678 , which characterizes such a statistical relationship as significant.

In the earing phase without pre-sowing seed treatment, a strong degree of statistical relationships was established between the assimilation surface of triticale plants and grain yield. The coefficient of determination is 0.824 . During pre-sowing seed treatment, a very strong statistical relationship was established between these indicators. The coefficient of determination was set at 0.901 .

Pre-sowing treatment of seeds with bacterial liquid fertilizer EscortBio increased the photosynthetic potential in all nutrition options. On average, for factor $\mathrm{A}$, this increase in the triticale was 0.05 million $\mathrm{m}^{2} / \mathrm{ha}$ days or $2.6 \%$ (Table. 2 ).

An important indicator of the photosynthetic activity of crops is the net productivity of photosynthesis, which characterizes the efficiency of the assimilation surface and reflects the real possibilities of agrobiocenosis in relation to the synthesis of organic matter more fully than the leaf area. 
Table 2

Photosynthetic potential of spring triticale sowing for the period tillering - earing (average for 2014-2016 yrs), $\mathrm{mln} . \mathrm{m}^{2} / \mathrm{ha}$ days

\begin{tabular}{|c|c|c|c|c|c|c|c|c|c|c|}
\hline \multirow[b]{2}{*}{$\begin{array}{c}\text { Seed } \\
\text { treatment } \\
\text { (factor B) }\end{array}$} & \multicolumn{10}{|c|}{ Variant of nutrition (factor $\mathbf{A}$ ) } \\
\hline & 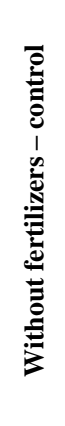 & 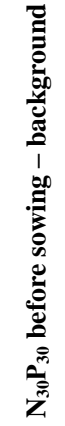 & 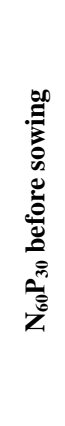 & 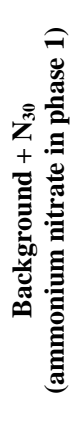 & 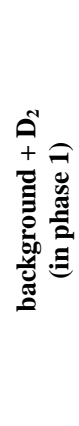 & 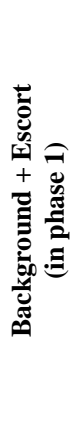 & 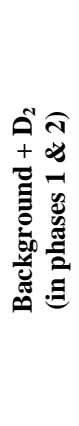 & 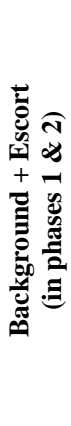 &  & 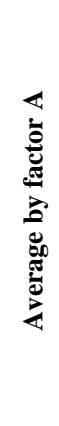 \\
\hline $\begin{array}{l}\text { Without seed } \\
\text { treatment }\end{array}$ & 1,44 & 1,63 & 2,07 & 2,01 & 2,00 & 2,01 & 2,01 & 2,01 & 2,01 & 1,91 \\
\hline $\begin{array}{l}\text { With seed } \\
\text { treatment }\end{array}$ & 1,47 & 1,68 & 2,12 & 2,07 & 2,06 & 2,06 & 2,05 & 2,06 & 2,04 & 1,96 \\
\hline $\begin{array}{c}\text { Average } \\
\text { by factor B }\end{array}$ & 1,46 & 1,66 & 2,10 & 2,04 & 2,03 & 2,04 & 2,03 & 2,04 & 2,03 & 1,94 \\
\hline
\end{tabular}

We also determined the net performance of photosynthesis of spring triticale seeding and its changes under the influence of optimal nutrition (table 3).

The calculated polynomial correlation-regression relationships determine that there is a very strong relationship between the net photosynthesis productivity and the yield of triticale grains, both in versions with pre-treatment of seeds and without it. The value of the determination coefficient (R2) defined by us ranges from 0.928 to 0.949 , that is, it ranges from 0.9 to 1.0 , which on the Cheddar scale characterizes such a statistical relationship as very strong. 
Table 3

Net photosynthetic productivity of spring triticale for the period of tillering - earing (average for 2014-2016 $\mathrm{yrs}$ ), $\mathrm{g} / \mathrm{m}^{2}$ per day

\begin{tabular}{|c|c|c|c|c|c|c|c|c|c|c|}
\hline \multirow[b]{2}{*}{ 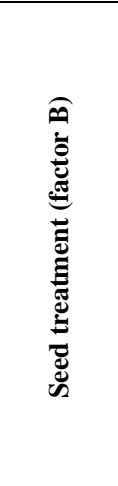 } & \multicolumn{10}{|c|}{ Variant of nutrition (factor $\mathrm{A}$ ) } \\
\hline & 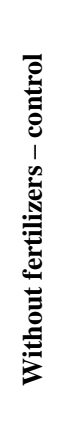 & 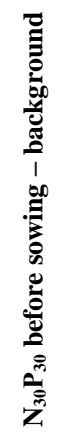 & 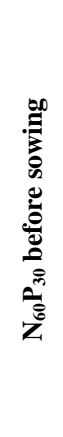 & 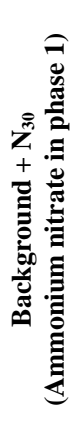 & 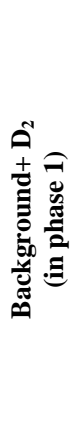 & 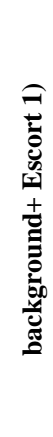 & 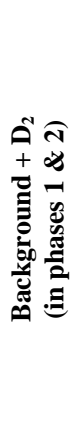 & 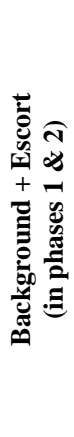 & 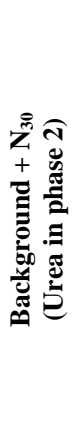 & 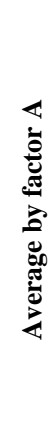 \\
\hline $\begin{array}{l}\text { Without } \\
\text { seed } \\
\text { treatment }\end{array}$ & 2,25 & 2,92 & 2,40 & 2,92 & 2,61 & 2,64 & 2,57 & 2,58 & 2,53 & 2,60 \\
\hline $\begin{array}{l}\text { With seed } \\
\text { treatment }\end{array}$ & 2,38 & 3,11 & 2,65 & 3,19 & 2,78 & 2,81 & 2,77 & 2,77 & 2,71 & 2,80 \\
\hline $\begin{array}{c}\text { Average } \\
\text { by factor B }\end{array}$ & 2,32 & 3,02 & 2,53 & 3,06 & 2,70 & 2,73 & 2,67 & 2,68 & 2,62 & 2,70 \\
\hline
\end{tabular}

\section{CONCLUSIONS}

The article justifies that the triticale culture is relatively new, so far little common and insufficiently investigated plant, which has winter and ravine forms. It is characterized by high agroecological plasticity to growing zones, and in terms of winter resistance, its winter form is dominated by winter wheat and barley.

The article also contains research materials on the impact of nutritional optimization on the growth processes of plants of the spring and winter triticale, their accumulation of above-ground biomass, assimilation apparatus, etc. It was established that mineral fertilizers, treatment of seeds and plants with modern biologics on the background of mineral fertilizer significantly increases all the investigated indicators of the growth processes of triticale plants.

So, already in the phase of plant smoking, the spring triticale from pre-treatment of seeds, the accumulation of above-ground biomass increased significantly compared to control (for treating seeds with water). The amount of raw material during this period of vegetation increased by $10.8 \%$, and dry - by $11.8 \%$. In subsequent phases - the release of plants into the tube and the spikes of the growth of above- 
ground biomass grew by $9.7-10.1 \%$ only from the start of seed treatment before sowing. Extracorporeal feeding with nitrogen fertilizer or biologics more significantly increased these indicators compared to the control, as well as average daily increases in individual periods - up to 3 times on average.

Accordingly, when exposed to nutritional optimization, the assimilation surface area of triticale plants, photosynthetic potential and net photosynthesis performance increased. Close correlation relationships are determined between most of the indices that characterize the growth processes of plants in the spring triticale and the level of grain yield.

Winter triticale plants also reacted significantly with a similar dependence on improving nutritional conditions. Thus, if $37.0 \mathrm{~g} / \mathrm{m}^{2}$ of raw aboveground mass was accumulated in the control during the autumn bush, then in fertilized versions this indicator increased to $443.3 \mathrm{~g} / \mathrm{m}^{2}$, and in the spring smoking phase (resumption of spring vegetation), respectively, from 1297.6 to $1735.0 \mathrm{~g} / \mathrm{m}^{2}$. Already at the time of the beginning of spiking, when, in the presence of livestock farming and the need for juicy feed, triticale crops are mowed to green mass, the above-ground biomass of fertilized plants grew to $69.4 \%$ compared to the control (35.0 and 59.3 tons/ha were formed, respectively).

So, we hope that our research on improving the nutrition of winter and spring triticale plants, as one of the main effective influences on the level of crops and grain quality, will contribute to the wider introduction of this valuable crop into production and the expansion of the areas occupied by them, including in the southern Steppe zone of Ukraine.

\section{SUMMARY}

The crop of spring and winter triticale is still sparsely distributed, but it is characterized by high plasticity, winter hardiness and grain quality. Studies have determined that this grain crop is able to enhance growth processes under the influence of improved nutrition. Seed treatment before sowing, application of mineral fertilizers and top dressing of crops with biopreparations helps to increase the height of plants, accumulate biomass, increase the leaf surface area, and so on. So, during the autumn tillering period, winter triticale plants in the control accumulated $372 \mathrm{~g} / \mathrm{m}^{2}$ of raw aboveground biomass, then in fertilized versions this indicator increased up to $443.3 \mathrm{~g} / \mathrm{m}^{2}$, and in spring during the resumption of spring vegetation it increased respectively 1297.6 up to $1735.0 \mathrm{~g} / \mathrm{m}^{2}$. 
Close correlations between individual plant growth indicators and the level of grain yield are determined.

\section{References}

1. Рябчун Н. І. Методологічні основи визначання зимостійкості, моніторингу посівів та формування урожайності озимих зернових культур : автореф. дис. ... д-ра с.-г. наук, спец. 06.01.09. Харків, 2015. $47 \mathrm{c}$.

2. Гамаюнова В. В., Дворецький В. Ф., Сидякіна О. В., Глушко Т. В. Формування надземної маси ярих пшениці та тритикале під впливом оптимізації їх живлення на Півдні України. Вісник ЖНАЕУ. Житомир, 2017. № 2 (61). Т. 1. С. 20-28.

3. Біднина I. О., Влащук О. С., Козирєв В. В., Томницький А. В. Ефективність сумісного застосування добрив та мікробних препаратів при вирощуванні сільськогосподарських культур на півдні України. Зрошуване землеробство. Херсон, 2013. № 60. C. $54-56$.

4. Господаренко Г. М., Любич В. В. Реакція сортів тритикале ярого на рівень азотного живлення. Збірник наукових пращь Уманського державного аграрного університету. Серія Агрономія. Умань, 2009. Вип. 72. Ч. 1. С. 21-29.

5. Гамаюнова В. В., Дворецький В. Ф., Сидякіна О. В. Формування врожаю тритикале ярого залежно від фону живлення та передпосівного оброблення насіння. Наукові горизонти, «Scientific Horizons». Zhytomyr, 2018. №7-8 (70). C. 3-9.

6. Любич В. В. Вплив азотного живлення на врожайність і кормові властивості зерна тритикале ярого. Науковий вісник Львівського національного університету ветеринарної медицини та біотехнологій ім. С. 3. Гжицького. Львів, 2009. Т. 11. № 2-3 (41). C. 131-135.

7. Філоненко Т. А. Забезпеченість сільськогосподарських культур елементами живлення та їх урожайність залежно від застосування зростаючих доз азотних добрив. Вісник Харківського національного аграрного університету. Серія: Грунтознавство, агрохімія, землеробство, лісове господарство. Харків, 2015. № 1. C. $130-137$.

8. Андрійченко Л. В. Шляхи підвищення врожайності та якості зерна твердої ярої пшениці на Півдні України. Вісник аграрної науки Причорномор'я. Миколаїв, 2006. С. 28-33. 
9. Шевніков Д. М. Вплив мінеральних добрив на поживний режим грунту за вирощування пшениці твердої ярої. Вісник Полтавської державної аграрної академії. Полтава, 2012. № 2. C. 203-206.

10.Білітюк А. П. Агротехнологічні основи вирощування тритикале в Україні. Агроном: науково-виробничий журнал. Київ : ТОВ «Агромедіа», 2005. № 3. С. 26-30.

11. Медведев А. М., Медведева Л. М. О недостатках и преимуществах тритикале в сравнении с другими зерновыми растениями. Тритикале России: материаль заседания секиии тритикале. Ростов-на-Дону : РАСХН, 2008. Т. 67. С. 140-146.

12.Білітюк А. П., Шустер Н. Ф. Вирощування інтенсивних агроценозів тритикале озимого в умовах Західного Полісся України. Збірник наук. праць Волинського інституту АПВ. Луцьк, 2006. C. $72-87$.

13. Щипак Г. В., Петрова А. П., Шевченко Е. Н., Щипак В. Г. Результаты селекции озимой тритикале на урожайность, зимостойкость и качество зерна. Вісник ЦНЗ АПВ Харківської області. Харків, 2010. Вип. 9. С. 179-188.

14. Синеговская В. Т., Абросимова Т. Е. Активизация фотосинтетической деятельности яровой пшеницы при длительном применении удобрений. Вестник Российской академии с.-х. наук. 2006. № 5. С. 45-53.

15. Gamayunova V., Sydiakina O., Dvoretskyi V., Markovska O. Productivity of Spring Triticale under Conditions of the Southern Steppe of Ukraine. Ecological Engineering \& Environmental Technology. 2021. № 22(2). P. 104-112. URL: https://doi.org/10.12912/27197050/133456.

Information about the authors: Gamayunova Valentyna Vasylivna,

Doctor of Agricultural Sciences, Professor, Head of the Department of Agriculture, Geodesy and Land Mykolayiv National Agrarian University 9, Georgiya Gongadze str., Mykolayiv, 54020, Ukraine

Chaikina Olena Ihorivna, Postgraduate Student Mykolayiv National Agrarian University 9, Georgiya Gongadze str., Mykolayiv, 54020, Ukraine 